\title{
Experimental Study for Phycoremediation of Botryococcus sp. On Greywater
}

\author{
P.Gani ${ }^{1 *}$, N.M.Sunar ${ }^{2}$, H.M.Matias-Peralta ${ }^{3}$, A.A.Latiff ${ }^{1}$, N.S. Kamaludin ${ }^{1}$, \\ U.K. Parjo ${ }^{2}$, Q. Emparan ${ }^{1}$, C.M. Er ${ }^{1}$
}

${ }^{1}$ Department of Water And Environmental Engineering, Faculty of Civil And Environmental Engineering (FKAAS), University Tun Hussein Onn Malaysia (UTHM) 86400, Parit Raja, Batu Pahat,Johor, Malaysia

${ }^{2}$ Department of Chemical Engineering Technology, Faculty of Engineering Technology (FTK), Universiti Tun Hussein Onn Malaysia (UTHM), 86400, Parit Raja, Batu Pahat, Johor, 86400, Parit Raja, Batu Pahat, Johor, Malaysia

\author{
${ }^{3}$ Department of Technology and Heritage, Faculty of Science, Technology and Human \\ Development (FSTPI) University Tun Hussein Onn Malaysia (UTHM) 86400, Parit Raja, Batu \\ Pahat, Johor, Malaysia \\ 1* parancgat@yahoo.com, ²shuhaila@uthm.edu.my, ${ }^{3}$ monica@uthm.edu.my, ${ }^{1}$ aziz@uthm.edu.my, \\ 1quinston89@gmail.com, 2umi5506@yahoo.com, 'erchinming@hotmail.com, \\ 1nabilasyazwanie@gmail.com
}

Keywords: Botryococcus sp.; Phycoremediation; Greywater; Microalgae

\begin{abstract}
Greywater (GW) is identified as waste disposal from home activites that is discharging from laundry, bath and wash-basin. GW useful in irrigation of a garden and aids to reduce cost as well as maintain the environmental prosperity. This paper discussed the effectiveness of Botryococcus sp. to clean $\mathrm{GW}$ in phycoremediation treatment. This process involves as growing the Botryococcus sp. in the GW which is contributing to utilize supplements in GW for its grow. The results indicated that Botryococcus sp. is effective to reduce COD (88\%), BOD (82\%), TIC (76\%), TC (58\%), TN (52\%), TOC (39\%), Phosphate $(37.5 \%)$ and $\mathrm{pH}(7 \%)$ for $100 \%$ concentration of GW. Meanwhile, for the $50 \%$ of GW concentration Botryococcus sp. capable to remove such as COD (83\%), TIC (82\%), BOD (68\%), TN (67\%), Phosphate (36.8\%), TC (34\%), TOC (31\%) and $\mathrm{pH}(1.2 \%)$. Then, the study concludes that Botryococcus sp. can grow effectively in $\mathrm{GW}$ and be able to reduce the rate of nutrient in $\mathrm{GW}$.
\end{abstract}

\section{Introduction}

Normally, GW contribute up to $70 \%$ of municipal wastewater volume [1]. Jefferson et al. [2] also found that, GW inclined to contain a few solids but less turbid if compared to domestic wastewater, recommendating that a lot of its pollutions are soluble. Cleaning activities from laundry, bath and wash-basin are mean source to GW. Soap and detergent is commonly alkaly where the $\mathrm{pH}$ of $\mathrm{GW}$ usually about 7-8 [2]. In addition, others wastewater contained high concentrations of nitrate, phosphate, and potassium but small amounts of nutrients could be detected in $\mathrm{GW}$, and sometimes more than $5 \mathrm{mg} / \mathrm{L}$ [2]. GW has characteristics different from home to home based on the personal behavior of the population and the equipment used in the home. Besides that, $\mathrm{GW}$ is also contain high of microbes. Survey of various parametric studies that include microbial characteristic $[3,4]$ show that kitchen sinks are often highly polluted effluents due to the presence of particles of food and oil as well as harmful to higher charges of salmonella in these streamsh. In addition, treatment and disposal of GW is an expensive and environmentally sensitive problem. The risk to health of chemicals when applied to land has been reviewed by Dean and Suess [5]. It also 
contains pathogens human germs, bacteria, viruses, and parasites whereas sludge smells can lead to respiratory problems and death.

A technique wastewater for reuse is by cultivating microalgae in lakes and retention ponds. Therefore, aim of the study is to verify the efficiency of the Botryococcus sp. in phycoremediation process of GW. Other than that, to evaluate the growth of microalgae in GW by counting the cell using haemocytometer. By that, algae grow is assumed to remove the phosphorus and nitrate existing and may useful as alternative to avoid water contamination.

\section{Materials and Methods}

\subsection{Sampling of Greywater}

The GW samples were sampling from residential area located at Parit Raja, Johor, Malaysia. The samples were collected and transferred into a bottle. Once reach the microbiology lab, the samples were kept at $4^{\circ} \mathrm{C}$ prior to be used for laboratory analysis.

\subsection{The Preparation of Botryoccocus sp.}

The Botryococcus sp. Colonies was provided by Microbiology Laboratory FTK, Universiti Tun Hussein Onn Malaysia. This ready for inoculation for preperation of treatment media. The inoculum was calculated by haemocytometer under light microscope. Algae inoculum of $1.0 \times 10^{3} \mathrm{cell} / \mathrm{ml}$ was inoculated to the treatment media. Then, clonical flasks was put in the indoor condition. The Botryococcus sp. cultivated in 7 samples for 17 days. The phycoremediation has to be classified into negative and positive. Flasks were put under the direction of natural light and gently shaking daily to make sure the algae are well mixed with sample while phycoremediation process. The volume of sample in the flask was $170 \mathrm{ml}$ for each of them. The triplicate contains $50 \%$ of sample was diluted with $50 \%$ using distilled water. Meanwhile, $100 \%$ of concentration, $170 \mathrm{ml}$ of GW is used for this process during 17 days. Negative control sample is prepared where contained $170 \mathrm{ml}$ of distilled water.

\subsection{Laboratory Test}

The characteristics such as BOD, COD, pH, Total Nitrogen (TN), Total Organic Carbon (TOC), Total Carbon (TC) and Inorganic Carbon (IC) was carried out based on the standard method and examination of water and wastewater (2009). Dairy wastewater parameter was examined on the $0^{\text {th }}$ day, $7^{\text {th }}$ day, $11^{\text {th }}$ day and $17^{\text {th }}$ day of phycoremediation.

\subsection{Microalgae growth measurement}

Growth of Botryococcus sp. was measured using Hemocytometer to count the number of microalgae cell. The step to use this materials, firstly ensure the cover-slip and haemocytometer were clean and pipette cell mix $10 \mu \mathrm{l}$ at the edge of the cover slip and allow running under the cover slip. Then, visualize the haemocytometer grid under the microscope at low magnification (10-20X) and adjust the focus of the lenses until individual counting grids are visible. 


\section{Result and discussion}

\subsection{Raw characteristics of Greywater (GW)}

Table 1 presents the parameter of raw greywater (GW), control sample and standard limits according to Environmental Quality (Sewage \& Industrial Effluents Regulation, DOE, 2009.). All parameter in $\mathrm{mg} / \mathrm{l}$ except for $\mathrm{pH}$.

Table 1 Greywater Characteristic Data

\begin{tabular}{|c|c|c|c|c|c|c|c|c|}
\hline Parameter & $\begin{array}{c}\mathbf{C O D}, \\
\mathbf{m g} / \mathbf{L}\end{array}$ & $\begin{array}{c}\mathbf{B O D}, \\
\mathbf{m g} / \mathbf{L}\end{array}$ & $\mathbf{p H}$ & $\begin{array}{c}\text { TOC } \\
\mathbf{m g} / \mathbf{L}\end{array}$ & $\begin{array}{c}\text { TIC } \\
\mathbf{m g} / \mathbf{L}\end{array}$ & $\begin{array}{c}\text { TC } \\
\mathbf{m g} / \mathbf{L}\end{array}$ & $\begin{array}{c}\text { TN } \\
\mathbf{m g} / \mathbf{L}\end{array}$ & $\begin{array}{c}\text { Phosphate } \\
\mathbf{m g} / \mathbf{L}\end{array}$ \\
\hline $\begin{array}{c}\text { Concentration } \\
\text { (n=3) }\end{array}$ & 183 & 224 & 7.4 & 64.9 & 32.15 & 54.82 & 19.30 & 12.7 \\
\hline $\begin{array}{c}\text { Distilled water with } \\
\text { Botryococcus sp. } \\
\text { (control) }\end{array}$ & 4 & 6 & 6.86 & 3.74 & 2.49 & 2.78 & 2.78 & 1.9 \\
\hline $\begin{array}{c}\text { Standard A } \\
\text { (DOE,2009) }\end{array}$ & 80 & 20 & $6-9$ & - & - & - & - & - \\
\hline $\begin{array}{c}\text { Standard B } \\
\text { (DOE,2009) }\end{array}$ & 200 & 50 & $5.5-9$ & - & - & - & - & - \\
\hline
\end{tabular}

\subsection{Analysis of Chemical Oxygen Demand}

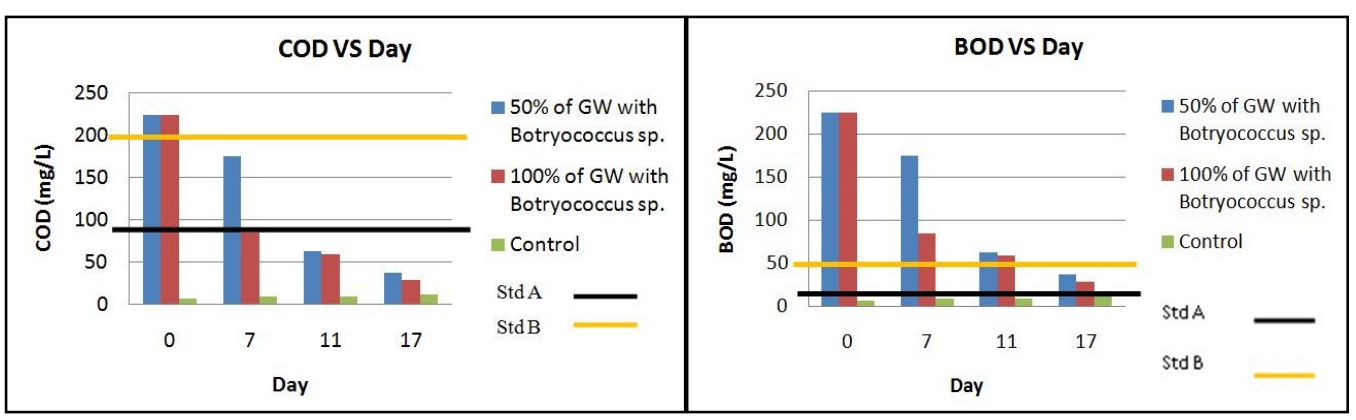

Figure 1 Removal of COD and BOD during phycoremediation

Figure 1 provides the removal of Chemical Oxygen Demand (COD) for $50 \%$ and $100 \%$ concentration of GW on $0,7,11$ and 17 days. It can be observed that both samples had a high COD concentration at the initial of the phycoremediation. Based on the trends produced, the Botryococcus $\mathrm{sp}$. has reveal a great removal in COD concentration, which is the total reduction efficiency for both concentration were $83 \%$ and $88 \%$ respectively. It indicates both samples were slightly declined on $7^{\text {th }}$ day and after that it drop drastically on day 15 . From this view, COD removal by Botryococcus sp. maybe can be increased with additional day phycoremediation periods.

Meanwhile, BOD removal for $50 \%$ and $100 \%$ of greywater. The start concerntration for BOD is $224 \mathrm{mg} / \mathrm{L}$. After initial day, BOD decreased to $175 \mathrm{mg} / 1$ for $50 \% \mathrm{GW}$. The flow is similarly to $100 \%$ concentration from day 0 to day 7 . After day 7, BOD for both concentration is slightly declined. Meanwhile, $100 \% \mathrm{GW}$ indicates the lowest of BOD which is $33.33 \mathrm{mg} / \mathrm{L}$. This may because of to the increment of DO during photosynthesis activity of Botrococcus sp.

\subsection{Analysis of pH}

Figure 2 shows $\mathrm{pH}$ level in $50 \%$ and $100 \%$ of concentration of GW. For $50 \%$ of GW, the $\mathrm{pH}$ level is higher when compared to $100 \%$. The $\mathrm{pH}$ increased to the neutral level. Acceptable limit for $\mathrm{pH}$ based on Standard A is 6-9 whereas for Standard B is 5.5-9. However, overall sample still in the range of acceptable $\mathrm{pH} . \mathrm{CO}_{2}$ has high potential to create a carbonic acid was assimilated by 
microalgae as nutrient resource. During oxidation process, normally $\mathrm{CO}_{2}$ is acidic when mixed with water. However, when photosynthesis occurred, $\mathrm{CO}_{2}$ was used to form a basic sugar rather than being permitted to shape carbonic acid. Thus, water reduced in acidic and at the same time $\mathrm{pH}$ was increase. Distinction in organic material has affected the grow of Botryococcus sp. Slow growth of microalgae was monitored in a $\mathrm{pH}$-tolerant algae when the $\mathrm{pH}$ over than 9.5 [6].

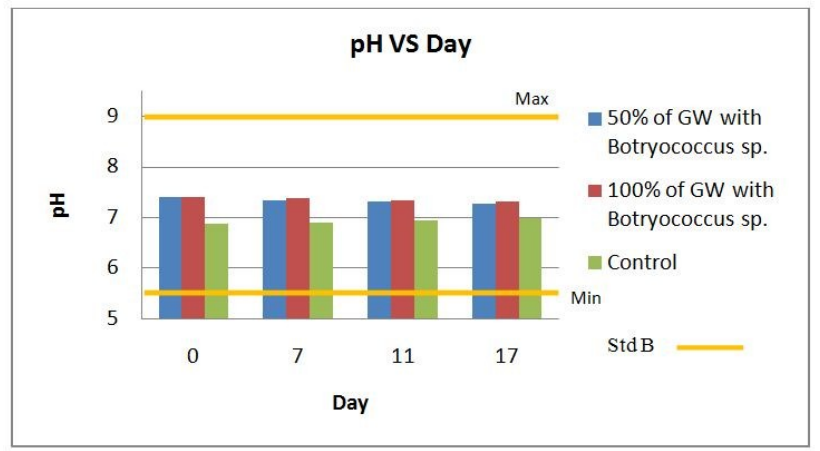

Figure $2 \mathrm{pH}$ during phycoremeditaion

\subsection{Analysis of TOC, TC and IC}
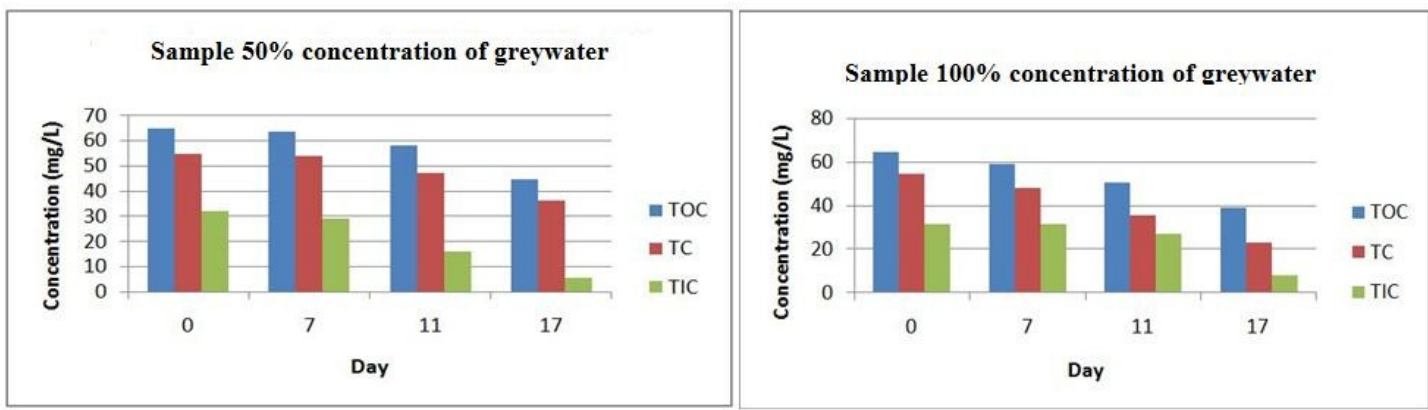

Figure 3 Graph of TOC, TC \& TIC in 50\% and 100\% concentration of GW during phycoremediation

Figure 3 shows the amount of TOC, TC and IC in 50\% of GW. It indicates that TOC was the highest if differentiated to other elements. TOC reduced from $64.90 \mathrm{mg} / \mathrm{L}$ to $44.85 \mathrm{mg} / \mathrm{L}$. The changes of TOC is as same as TC and TIC but TIC value is lower than TOC. In the meantime, TC is $5.63 \mathrm{mg} / \mathrm{L}$ at the end of phycoremediation process. However, most of the parameters show significant removal from day 0 to day 7 of treatment.

Meanwhile for $100 \%$ concentration, it can be viewed from the graph that there is a reduction in the value of TOC from $64.90 \mathrm{mg} / \mathrm{L}$ to $39.62 \mathrm{mg} / \mathrm{L}$. TIC also reduced from $32.15 \mathrm{mg} / \mathrm{L}$ to $7.86 \mathrm{mg} / \mathrm{L}$ and TC has reduced from $54.02 \mathrm{mg} / \mathrm{L}$ to $23.15 \mathrm{mg} / \mathrm{L}$. Normal organic carbon such as acetate or glucose are commonly favored by algae, but they also can take up various another compounds such as $\mathrm{N}$ and $\mathrm{P}[7]$.

\subsection{Analysis of Nitrogen, Phosphate and Nitrate}

Figure 4 shows concentration of nitrogen, phosphate and nitrate for both $50 \%$ and $100 \%$, respectively. All the data showed is almost the same flow of decrement. However, for $50 \%$ concentration, there is a slightly increase of phosphate on day 7 . This is probably due to the sample have been contented with other microbe before treatment. Then, the phosphate also has been removed steadily on the $11^{\text {th }}$ and $17^{\text {th }}$ day of phycoremediation. In the meantime, $100 \%$ 
concentration of GW showed a important reduction in the value of nitrogen and phosphate. Removal of nitrogen from $19.30 \mathrm{mg} / \mathrm{L}$ to $6.35 \mathrm{mg} / \mathrm{L}$, phosphate reduced from $12.7 \mathrm{mg} / \mathrm{L}$ to 7.46 $\mathrm{mg} / \mathrm{L}$ but nitrate has been increased from $7.4 \mathrm{mg} / \mathrm{L}$ to $7.86 \mathrm{mg} / \mathrm{L}$. Basically, nitrogen is needed for algae cultivation. Research about nitrogen supply prove that organizing nitrogen metabolic in Botryococcus sp. is the nitrate absorbtion process.

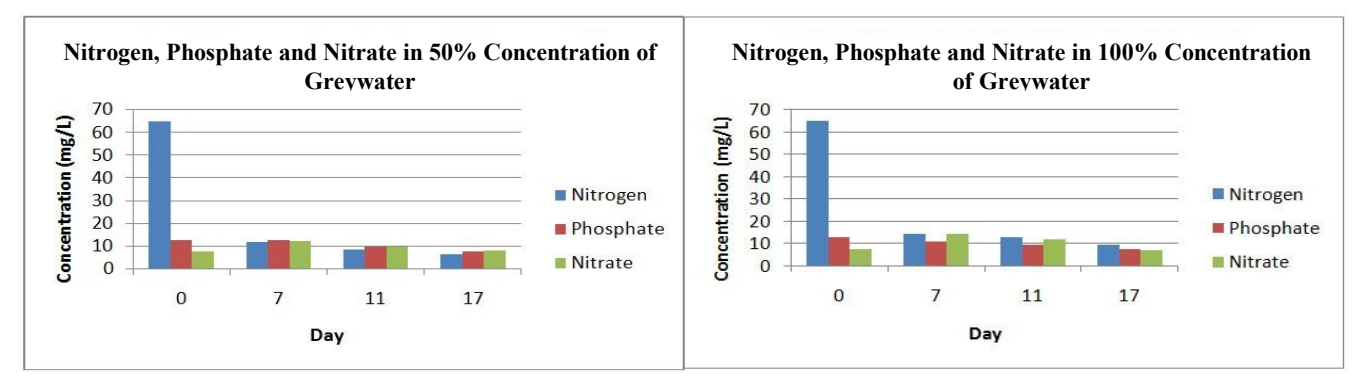

Figure 4 Concentration of Nitrogen, Phosphate and Nitrate

\section{Conclusion}

This study reveals that Botryococcus sp. is suitable as phycoremediation agent to bio-transform the pollutant load into microalgae cell. The usage of Botryococcus sp. for bioremediation in GW was effectively reduce the COD where begining value was $183 \mathrm{mg} / \mathrm{L}$ and the last value for $50 \% \mathrm{GW}$ after 17 days was $59 \mathrm{mg} / \mathrm{L}$ whereas for $100 \% \mathrm{GW}$ was $33.33 \mathrm{mg} / \mathrm{L}$. The $\mathrm{pH}$ level of the sample was decreased during the phycoremediation process. In addition, BOD concentration of raw GW before phycoremediation was higher up to $271 \mathrm{mg} / \mathrm{L}$ and drastically decreased from day 0 to day 7 for both concentrations. From overall finding, indicates a obvious difference of value by each parameters since the begining day until the end of phycoremediation. TOC, TC and TIC has decreased for each concentration.

\section{Acknowledgement}

The authors to thanks the support of any parties which is involved in this project especially Universiti Tun Hussein Onn Malaysia for providing the equipment research facilities to carry out this project and Geran Penyelidik Siswazah (GIPS).

\section{References}

[1] Friedler, E. (2004). Quality of individual domestic greywater streams and its implication for onsite treatment and reuse possibilities. Environmental Technology, 25(9), pp. 997-108.

[2] Jefferson, B., Palmer, A., Jeffery, P., Stuetz, R. \& Judd, S. (2004). Grey water characterisation and its impact on the selection and operation of technologies for urban reuse. Water Sci. Technol. 50(2). Pp. 157-64.

[3] Eriksson, E., Auffarth, K., Henze, M. \& Ledin, A. (2002). Characteristics of grey wastewater. Urban water. 25(9), pp. 997-1008.

[4] Lazarova, V., Hills, S. \& Bricks, R. (2003). Using recycled water for non-potable, urban uses: a review with particular reference to toilet flushing. Water Supply. 3(4), pp.69-77.

[5] Dean, R.B. and Suess, M.J. (1985). The risk to health of chemicals in sewage sludge applied to land. Waste management and research. 3, pp. 251-278. 
[6] Pendersen, M.F. and Hensen, P.J. (2003). Effects of high $\mathrm{pH}$ on the growth and survival of six marine heterotrophic protests. Mar. Ecol. Prog. Ser. 260. Pp. 33-41.

[7] Lee. K. And Lee, C.G. (2001). Effect of light/dark cycles on wastewater treatments by microalgae. Biotechnology Bioprocess Eng. Pp. 194-199.

[8] Banerjee, A., Sharma, R., Chisti, Y. \& Banerjee, U.C. (2002). Botryococcus braunii: a renewable sources of hydrocarbons and other chemical. Critical Reviews in Biotechnology, 22(3), pp. 245-79.

[9] Lupi, F.M., Fernandes, H.M.L., Sa-Correia, I. \& Novais, J.M. (1991). Temperatures profiles of cellular growth and exopolysaccharide synthesis by Botyrococcus braunii Kutz. UC 58. J. Appl.Phycol. 3., pp. 35-42. 